Fiener, P., K. Auerswald 2017. Grassed Waterways. In: J. Delgado, G. Sassenrath, T. Mueller, editors, Precision Conservation: Geospatial Techniques for Agricultural and Natural Resources Conservation, Agron. Monogr. 59. ASA and CSSA, Madison, WI. p. 131-150. doi:10.2134/agronmonogr59.2013.0021

\title{
Grassed Waterways
}

\section{Peter Fiener* and Karl Auerswald}

\begin{abstract}
Grassed waterways (GWWs) are a widely used best management practice (BMP) in countries with large-area farming. They are broad, shallow, grass-lined channels often located within large fields and have the primary function of draining surface runoff from farmland and preventing gullying along the natural drainage ways. They are rarely found in areas with relatively small fields, for example, in many European countries, where a single GWW would drain a number of fields. Presently, GWWs seem to attract much less attention as BMPs than grassed or vegetated filter strips at the downslope end of fields or along the surface of bodies of water, even though the benefits of GWWs are obvious. Studies clearly show that well-established GWWs effectively prevent gully erosion, reduce sediment and agrochemical delivery, and dampen peak discharge rates. The effects of GWWs on plant and faunal diversity are insufficiently studied, and our knowledge of them is based mostly on analogies from grass strips or set-aside areas. Use of such analogies might be especially misleading with regard to the effects of GWWs on ecological connectivity within arable landscapes. From an agricultural viewpoint, the benefits of GWWs clearly seem to overcompensate for the main disadvantage: loss of land for cultivation. But arriving at general conclusions is difficult due to the huge variation in land prices and establishment costs. In economic terms, GWWs are thought to have a life span of ten years, a misjudgment that may be responsible for less relevance of GWWs since the 1970s. From political and societal viewpoints, outreach programs and financial incentives appear to be good investments. Apart from effectively preventing erosion damage (e.g., muddy floods), society would benefit from other ecological effects that are not included in the economic considerations of farmers. But scientific knowledge regarding the ecological and economic benefits and economic costs of GWWs is incomplete, impeding a holistic assessment of them. This is the case regarding the obviously intended effects on sediment delivery and discharge from agricultural land, because watershed-scale studies are rare and available modeling approaches therefore lack rigid testing.
\end{abstract}

Abbreviations: BMP, best management practice; GWW, grassed waterway.

P. Flener, Institut für Geographie, Universitát Augsburg, Alter Postweg 118, 86159 Augsburg, Germany; K. Auerswald, Lehrstuhl für Grünlandlehre, Technische Universităt München, Alte Akademie 12, 85354 Freising, Germany (auerswald@wzw.tum.de). "Corresponding author (fiener@geo.uni-augsburg.de).

doi:10.2134/agronmonogr59.2013.0021

(c) ASA, CSSA, and SSSA, 5585 Guilford Road, Madison, WI 53711, USA.

Precision Conservation: Geospatial Techniques for Agricultural and Natural Resources Conservation

J.A. Delgado, G.F. Sassenrath, and T. Mueller, editors. Agronomy Monograph 59. 
rassed waterways were widely implemented as a BMP to control (ephemeral) gully erosion in the 1970s and 1980s in North America (Atkins and Coyle, 1977; Berg and Gray, 1984; Napier et al., 1984; Bracmort et al., 2004). They are broad, shallow, grass-lined channels often located within large fields and have the primary functions of draining surface runoff from farmland and preventing gullying along the natural drainage ways (Fig. 1). Berg and Gray (1984) reported that in some US counties, up to $90 \%$ of all farmers interviewed had GWWs. Grassed waterways were also established in other countries that typically have large-area farming (e.g., Australia; Thomas et al., 2007). Compared with those countries, GWWs are rarely found in Central Europe, even though some authors (e.g., Fiener and Auerswald, 2003b; Evrard et al., 2008b; Boardman and Vandaele, 2016) have shown their potential as a BMP for small-area farming in Europe. But in many areas of the world, increasing globalization has resulted in trends in agriculture-such as larger field sizes and use of a greater proportion of arable land-that increase the demand for GWWs and create the preconditions for their establishment. In general, the emphasis is less on GWWs than on grass or vegetative filter strips at the downslope end of agricultural fields and along open bodies of water. This is especially indicated by a SCOPUS search (October

A

B
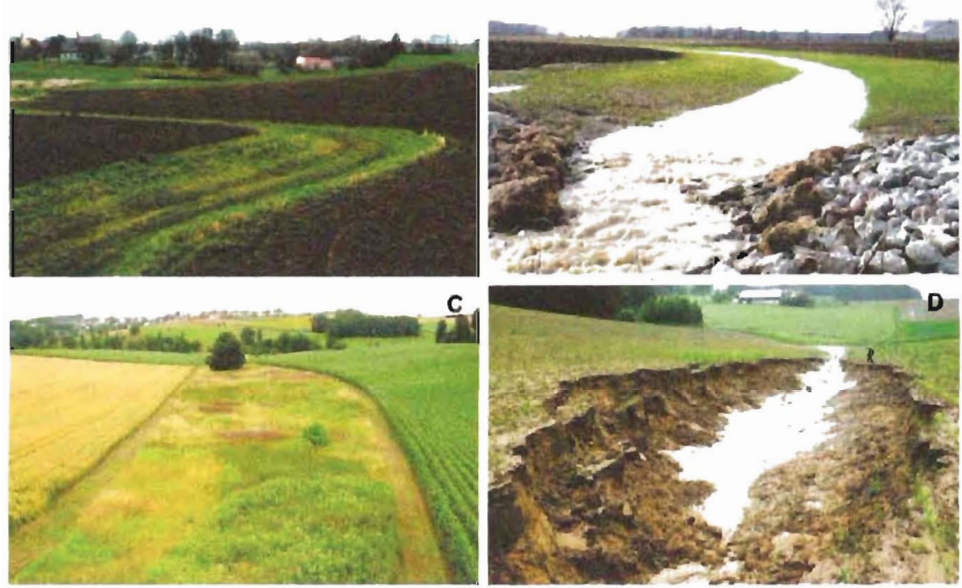

Fig. 1. (A) Narrow, subsurface grassed waterway (GWW) in Belgium with triangleshaped cross-section for fast drainage applicable for small drainage areas but with risk of overtopping or incision at high runoff rates (photo by $C$. Bielders). (B) Wide, flatbottomed GWW for large runoff rates and rock chute outlet to prevent incision (photo by K. Schneider, USDA Natural Resources Conservation Servlce). (C) Successional GWW in Germany with large hydraulic roughness and high biotic value due to the provision of habitat, feed, and connectivity for wild species. The margins have been mulched to prevent weed encroachment in the fields and to facilitate runoff inflow into the waterway (photo by G. Gerl). (D) Massive gullying (see person in background for scale) has been initiated by a single runoff event due to the lack of a GWW along the dralnage line (photo by $R$. Brandhuber). 
2014) that resulted in approximately seven times more hits for vegetative/grass filter strips than for vegetative/grassed waterways. There are two possible reasons for the difference in interest and scientific knowledge about these two BMPs: (i) the implementation of a GWW along drainage areas is more complex, and hence less common, especially under European conditions, where several fields might drain into one GWW; and (ii) landscape-scale experiments are more challenging (and costly) for experimentally evaluating the effects of GWWs compared with measurements in small grass strips, which are often used in plot experiments.

Assessment of GWWs as a BMP calls for a holistic evaluation of their agronomic (or economic) and ecological effects. The objective of this review is to provide such a view while synthesizing results from studies performed within the last four decades on the economic and ecological effects of GWWs. Political options and constraints on supporting the establishment of GWWs are identified, and gaps in the scientific knowledge are discussed.

\section{The Agricultural Viewpoint}

Use of GWWs is in direct proportion to the environmental concern of farmers, their agricultural education, and the acreage farmed (Napier et al., 1984); conversely, the adoption of double cropping while holding share leases reduces the adoption rate of GWWs (Nyaupane and Gillespie, 2011). Grassed waterways are more likely to be amortized on owned land than on land leased for a short or unpredictable period of time. Given that there are different types of GWWs (Fig. 2) and that landscape properties and socioeconomic conditions vary, large differences in costs can be expected. Grassed waterways may be engineered (Fig. 1A $1 \mathrm{~B}$, and 2B-2D), as in the case of perched GWWs, which are not placed at the location where the topography would concentrate the water, or in the cases in which GWWs are used to drain constructed terraces. Alternatively, they may just be setasides at positions within sloping land where water concentrates naturally and thus do not entail much in the line of construction costs (Fig. 1C and 2A). We will discuss the associated costs, which comprise (i) installation costs that have to be depreciated over the life time of the GWW (including interest rates), (ii) maintenance costs, and (iii) the opportunity cost for the land occupied by the GWW (Kling et al., 2007; Qiu et al., 2009; Chen and Barkdoll, 2013).

\section{Installation Costs}

Few or no costs accrue if the area of the GWW is simply taken out of production (Fig. 1C and 2A) or if only a few or small improvements are necessary. Evrard et al. (2008a) calculated the costs of installing earthen detention ponds within GWWs to be $€ 126 \mathrm{ha}^{-1}$. Seeding of sod-forming species may be necessary when such species would not establish naturally. In contrast, the construction of engineered GWWs usually will cost in the range of $\$ 4000$ (or $€ 4000$ ) ha $\mathrm{h}^{-1}$ (Kling et al., 2007; Qiu et al., 2009; Chen and Barkdoll, 2013). Engineered GWWs can be among the most expensive measures of erosion control. Such GWWs usually become necessary when other installations, such as terraces, require the GWW to be in a certain position, at a certain level within the land, and have a certain capacity: all variables that are defined by the other installations. Thus, economically, the costs are not caused by the GWW itself but are subsequent costs resulting from other 



e) Ineflective grassed waterway

\section{Fig. 2. Typical cross-sections of grassed waterways.}

installations; superficially, however, those costs are associated with the construction of the GWW.

Nevertheless, installation costs exist and need to be covered. Whether they are high or not largely depends on the design life of a GWW. A design life of $10 \mathrm{yr}$ is commonly assumed, although it is not clear on which basis this estimate was made. In comparison, the design life of terraces is usually set at $20 \mathrm{yr}$ (Kling et al., 2007; Chen and Barkdoll, 2013). We are aware of only one study quantifying the endurance of GWWs. Bracmort et al. (2004) examined GWWs, the majority of which were built in the 1970s and 1980s, and found that among different structural BMPs, GWWs were the ones most likely to be used after more than 20 yr; they were functional beyond twice their design life. The GWWs studied by Chow et al. (1999) and by Fiener and Auerswald (2003a) were still functional $25 \mathrm{yr}$ after their establishment. A major reason that GWWs persist may be that farmers tend to discontinue farming practices (e.g, nutrient management) more frequently than structural practices such as GWWs (Osmond et al., 2012). A design life of 10 yr entails annual costs of about $\$ 400 \mathrm{ha}^{-1} \mathrm{yr}^{-1}$ for an engineered GWW, and these costs would be halved for a design life of $20 \mathrm{yr}$. Given that the study by Bracmort et al. (2004) is the only one that empirically determined the lifetime of GWWs, their design life should be changed to $20 \mathrm{yr}$, but further studies are clearly needed. A more sophisticated approach would recognize that their design life is variable and depends on a number of factors, the most important one perhaps being the management of the adjacent land.

Many farmers tend to consider the land occupied by GWWs to be a loss of valuable acreage (Carey et al., 2015a); as a consequence, there is a risk that not enough land is allotted for the GWW. Usually there is a trade-off between the amount of land allotted on the one hand and the installation costs, secondary benefits, and efficiency of a GWW to reduce runoff and sediment export on the other. Set-asides of natural flow paths usually lead to wide GWWs owing to the flat bottom of the drainage path (Fig. 1B, 1C, and 2A). Conversely, engineered 
GWWs such as subsurface GWWs or GWWs with banks (Fig. 1A, 2B, and 2C) concentrate the flow and thus reduce the need for area. Hence, secondary benefits are reduced and installation costs increase while less land is needed. It will depend on the cost of land (e.g., land rental costs) as to which expense is higher. Installation costs increase with decreasing GWW width because concentrating the flow will increase flow velocity (Fiener and Auerswald, 2005), which calls for a reinforcement of the GWW, and also decrease the retention capacity of the GWW and increase the likelihood of failure (Fig. 3). For a safe GWW, it is recommended that the Froude number (the ratio between the average flow velocity and the wave velocity) should not exceed 1 but should be in the range of 0.8 (Carey et al., 2015), which better describes the hydrodynamic properties of the runoff than simply using flow velocity as in Fig. 3. For a near-rectangular cross-section, wave velocity may be approximated by the square root of gravitational acceleration times flow depth. A Froude number of more than 1 indicates that hydraulic jumps will occur that release much of the flow energy locally and thus may initiate gully formation as typically shown in Fig. 1D. When Froude numbers less than 1 cannot be guaranteed, additional measures such as the reinforcement of the GWW bottom by UV-resistant nets or geotextile mats become necessary (Carey et al., 2015a, 2015b). Although non-engineered GWWs may be adopted by the farmer without technical assistance, the trade-off between GWW width and functionality benefits from the input of an expert who is aware of the hydromechanical properties of a GWW. In some countries, detailed handbooks for the design of GWWs are available that describe how to professionally install GWWs (e.g., in the United States, USDA-SCS, 1954; Temple et al., 1987; in Australia, Carey et al., 2015a), while in other regions of the world such technical support is widely missing.

\section{Maintenance Costs}

Maintenance costs are usually small and may range from $\$ 10$ to $\$ 40 \mathrm{ha}^{-1} \mathrm{yr}^{-1}$ (Qiu et al., 2009; Chen and Barkdoll, 2013). One of the primary maintenance functions is occasional grass cutting to prevent encroachment of woody species and

Fig. 3. Permissible runoff velocities in grassed waterways at low risk of erosion (low-erodible soil and $100 \%$ cover), medlum rlsk (elther low-erodible soil and $70 \%$ cover or high-erodible soll and $100 \%$ cover), and high risk (high-erodible soil and $70 \%$ cover). After Titmarsh and Stone, 1997.

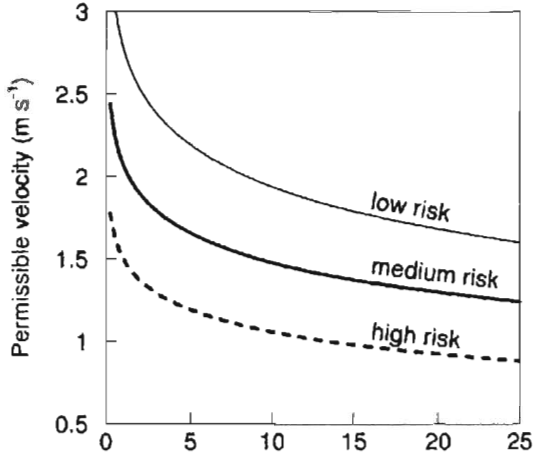

Gradient (\%) 
to favor sod-forming species and a dense rooting structure close to the soil surface. Higher maintenance costs occur if the GWW is damaged by sedimentation or if it loses the capacity to accommodate runoff because of furrows along its sides (Fig. 2E). In both cases, the problem is not the GWW itself but the improper management of the surrounding land; hence, the costs would better be assigned to the land rather than to the GWW. Furrows along the side usually result from improper tillage that either creates the furrows or that forms a dam that prevents the runoff from entering the GWW. The runoff will then flow along the unprotected sides of the GWW and produce a rill. Sediment will fill the GWW only if high erosion rates occur within the delivering watershed. Even then, an obstruction will probably not form in a GWW because the concentrated flow will always have a higher transport capacity than the shallow flow on the side slopes, where sediments are first trapped. The more the hydrodynamic resistance of the grass is reduced due to sedimentation, the less additional sedimentation will occur in the GWW. Complete burial of the grass is thus impossible except when the runoff is slowed down due to other conditions-for example, by detention ponds within the GWWs (Evrard et al., 2008a), by filter socks (Shipitalo et al., 2012), or by a meandering flow path (Titmarsh and Stone, 1997). In most of these cases, control of runoff is not due to the grass in the GWW, and damage to the grass would not be critical.

\section{Land Costs}

Grassed waterways occupy farmland but, despite their size, their share of overall land is small. Fiener and Auerswald (2006a) analyzed 19 watersheds, ranging in size from 50 to $1500 \mathrm{ha}$, and determined the amount of land that would be lost if a GWW were established wherever the topographical situation would allow for a seminatural GWW like the one in Fig. $1 \mathrm{C}$ and 2A. Assuming that all of it was used for arable purposes, only $2.3 \%$ of land would have been lost to GWWs. Thus, a farm's net return cannot be reduced by more than $2.3 \%$ even if no economic benefits exist. For the studied watersheds, which comprised mixed-use land, only $0.8 \%$ of the land qualified for GWWs (Fig. 4). Even so, construction of GWWs on this small portion of land would have reduced peak discharge by about $15 \%$.

The cost of land will vary significantly among countries. Chen and Barkdoll (2013) assumed approximately $\$ 150 \mathrm{ha}^{-1} \mathrm{yr}^{-1}$ (for the USA) for land rental for GWWs, while Spaan et al. (2010) assumed $€ 60,000 \mathrm{ha}^{-1}$ (for the Netherlands) was necessary to purchase the land for GWWs. But the question arises whether average costs for renting or purchasing arable land are applicable to GWWs. Usually a GWW is placed along the natural drainage line, where typically the most fertile, colluvial soils occur that were created by tillage erosion due to the decrease in slope inclination. The colluvial soils in hollows resulting from tillage may lead to an erroneous expectation of a low potential hazard from water erosion, while in fact it often is maximum in this position (Van Oost et al., 2000; Fig. 1D). Due to the confluence of runoff from both side slopes, the flow width decreases and flow depth increases, leading to high flow velocities, which cause ephemeral gullies. Tillage closes the ephemeral gullies but also maintains the field's susceptibility to gullying. In some cases, no-till may reduce the risk of gullying (Gordon et al., 2008), but it will not always be sufficient, and it restricts land use across the entire field. In the case of the watersheds analyzed by Fiener and Auerswald (2003a, 2003 b), historical maps showed that a narrow strip of grassland had previously 




Fig. 4. Lauterbach watershed $\left(16.7 \mathrm{~km}^{2}\right)$ near Bonn in Western Germany. Analyzed for its potential to allocate grassed waterway in differently used sub-watersheds (examples left). Effects on runoff modeled for actual land use and assumed predominantly arable land use in all sub-watersheds (Fiener and Auerswald 2006a).

existed where they established their GWW but that this strip had been plowed and lost with the advent of mechanized agriculture. Mechanization makes it easier to close ephemeral gullies, but it would be misleading to apply the average costs of arable land that does not bear the risk of ephemeral gullying to all areas occupied by GWWs. Some farmers view GWWs as inconveniences that add to production costs and have uncertain economic returns (Chow et al., 1999). Zhou et al. (2009), however, showed that in many cases there was an economic benefit from GWWs even though they assumed costs of up to $\$ 11,000 \mathrm{ha}^{-1}$ and a life span of only $10 \mathrm{yr}$. 


\section{Benefits}

While costs are certainly of concern, it is interesting to note that a survey by Berg and Gray (1984) found that up to $90 \%$ of all interviewed farmers in some counties in the USA had GWWs. The majority of those farmers said that the main reason for using a particular practice was the expectation that it would reduce operating costs. A focus on the costs of GWWs is thus one-sided if their economic benefits are not considered. The most striking benefit is that GWWs prevent ephemeral gullies. Such gullies cost money to be removed and pose an obstacle during field operations because they often cannot be crossed with farm machinery (Fig. 1D). Conversely, GWWs allow equipment to travel to both sides of a field or across two fields. Additionally, the GWW can be used instead of the field margin for farming operations and thus improves field management at the margin. For example, turning operations can be moved from within the fields onto the GWWs to avoid soil compaction of the headland. However, it needs to be noted that moving traffic into the GWWs might be more appropriate for wide, seminatural GWWs but more problematic in narrow, more technical ones, because trafficking may decrease infiltration capacity within the GWWs and may also damage the grass sward in areas of concentrated flow. Regarding the damage to the sward, handbooks recommend not using GWWs as turnrows during tillage operations (USDA-SCS, 1954). Generally, GWWs should not be crossed when they are very wet, but except for those GWWs located on very shallow groundwater tables, using them as turnrows should not present a problem when fields are dry enough for field management. The large width in some places of one of the GWWs studied by Fiener and Auerswald (2003b) was unnecessary for the functioning of the GWW. It resulted from the design of the neighboring fields. The design aimed to create field widths that were multiples of farm-machinery widths $(15 \mathrm{~m})$. This reduced labor costs and efforts, reduced unintentional application of fertilizers and pesticides outside the field margins, and permitted more precise application of agrochemicals within the field margins and more precise tillage. Problems may arise and redesign may become necessary when machinery widths change, which is not improbable given the long life spans of GWWs. They are often considered an obstacle within the fields that create overlapping or nontarget application of agrochemicals because the field boundary becomes more complex (Luck et al., 2011b). However, GWWs can also be designed to have the opposite effect by optimizing field boundaries and thus not creating additional complexity. The complexity is already inherent in the variability of site conditions, particularly when there is uncontrolled erosion. Ignoring this complexity does not remove it but may create additional problems such as compaction of the wetter soils in the depressions, uneven ripening of the crops, or gullying. Engineered GWWs, however, such as those presented in Fig. 2B-2D, may become impassable and thus increase the difficulties for field management (Luck et al., 2011a). Seminatural GWWs (Fig. 2A) do not have this problem and can even be used occasionally as farm roads during dry conditions (Fig. 1C). The best type of GWW to choose thus depends primarily on the relative importance of different cost components. While seminatural GWWs need more land, they have lower installation costs and offer more potential benefits. 


\section{The Ecological Viewpoint}

From an ecological view, GWWs exhibit a multitude of beneficial effects on different ecosystem functions besides the most obvious and intended one of protecting against gully erosion and the associated reduction in sediment delivery into adjacent ecosystem compartments. Grassed waterways trap incoming sediments and associated particle-bound agrochemicals and nutrients; they reduce runoff volume, especially peak discharge and, as a consequence, also affect the delivery of dissolved nutrients; and they affect a number of ecosystem functions, such as biodiversity and soil carbon stocks.

\section{Reduction in Runoff}

Grassed waterways reduce runoff originating from adjacent fields mainly by the following three processes: they create (i) a higher rate of water infiltration due to reduced sealing of continuous grass cover compared to more exposed farmed soils and there is less soil compaction caused by wheeling; (ii) a prolonged time for infiltration because the hydraulic roughness provided by dense grass reduces runoff velocity (Ree, 1949; Ogunlela and Makanjuola, 2000); and (iii) a higher surface storage capacity than drainage ways without GWWs, which also results from the greater hydraulic roughness and greater interception of runoff during periods when drainage ways without GWWs exhibit no vegetation cover.

Compared with the large number of studies that deal with runoff reduction by vegetated filter strips located at the downslope end of fields or along small streams (Dillaha et al., 1989; Muñoz-Carpena et al., 1993; Deletic, 2001; Dass et al., 2011), there are relatively few studies evaluating reduced runoff by GWWs. More such studies are essential because GWWs have more-complex effects than filter strips. Grassed waterways affect the laterally incoming sheet flow in a manner similar to filter strips, but they also affect the concentrated runoff along the drainage way, an effect that does not occur in vegetated filter strips. Paired watershed studies (e.g., Chow et al., 1999; Fiener and Auerswald, 2003b) indicate that the runoff reduction potential of GWWs is large, but it also varies substantially depending on the watershed and the characteristics of the GWW. For example, in two pairs of watersheds with more or less identical land use and cropping patterns but different GWW characteristics, Fiener and Auerswald (2003b) found an average reduction in runoff volume across $8 \mathrm{yr}$ of $90 \%$ for a flat-bottomed GWW but a reduction of only $10 \%$ for a GWW with a small incision $(0.5 \mathrm{~m}$ wide and 0.2 $\mathrm{m}$ deep) along its drainage way that accelerated the runoff velocity. Chow et al. (1999) reported a reduction in runoff volume of $14 \%$ in four vegetation periods when comparing two watersheds: one with up-and-down slope cultivation and another with a terrace/GWW system (note: Chow et al. used only those vegetation periods in which identical crops were cultivated in both watersheds). The seasonal variability of GWWs in reducing runoff volume contributes to the variability of long-term means. Generally, high efficiencies can be expected during phases of small inflow volumes (Fig. 5A). Seasons with high hydraulic roughness due to stiff grasses (mainly during the growing season) or low antecedent soilwater contents will also experience higher efficiencies than other seasons (Fiener and Auerswald, 2006b). 

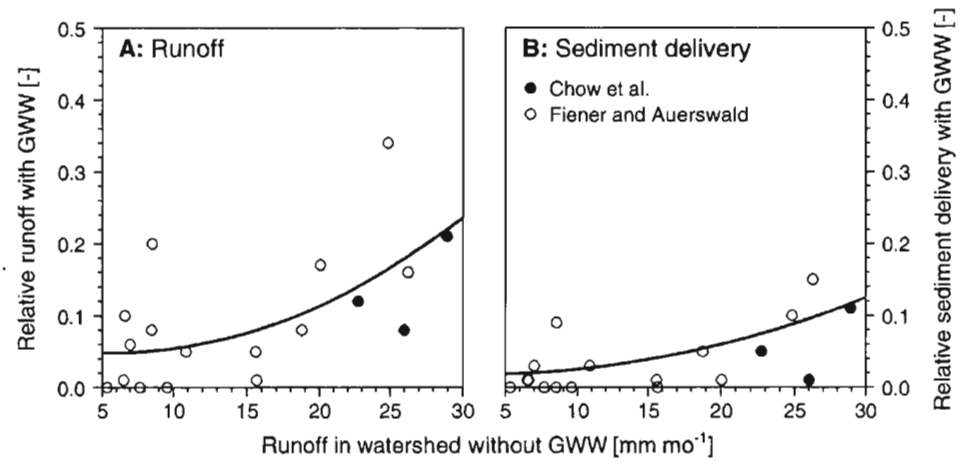

Fig. 5. Relative runoff $(A)$ and sediment delivery (B) from watersheds with grassed waterways (GWWs) versus data from paired watersheds without GWW. Monthly data of paired watersheds with the same soll conservation measures and crop rotations (winter wheat, potatoes, winter wheat, and maize) and a flat-bottomed GWW (from Fiener and Auerswald 2003b), and monthly mean of seasonal data (1 May to 30 November) of paired watersheds with the same crop rotation (potatoes, potatoes, barley, and potatoes) but one with a terrace/GWW system, and the other with up-anddown slope cultivation (Chow et al., 1999) are plotted.

Model-based evaluations (e.g., Hjelmfelt and Wang, 1997; Fiener and Auerswald, 2006a; Kalantari et al., 2014) predicted smaller reductions in runoff volume than paired watershed studies did (reductions of 5 and $30 \%$, respectively). These predictions resulted in part from the focus on large events rather than on longterm means, but the discrepancy may also be the result of a lack of appropriate parameterizations in the models, for example, high infiltration capacities in GWWs. However, all modeling studies consistently reported pronounced effects on peak discharge because of the larger hydraulic roughness and lower hydraulic radius than those of drainage ways without GWWs (reduction in peak discharges to values between 46 and $85 \%$ ). Irrespective of potential prediction errors in the runoff-volume reduction for GWWs, models are needed to upscale the efficiency of GWWs for catchment sizes for which experimental evidence is no longer available. Fiener and Auerswald (2006a), for example, modeled a $16.7-\mathrm{km}^{2}$ watershed in which GWWs were placed along the most suitable drainage ways in case of actual land use and assumed predominantly arable land use (Fig. 4). Depending on assumed storm reoccurrence (2-50 yr), season, and land-use scenario, the predicted runoff volume was reduced to values between 70 and $95 \%$, and predicted peak discharge was reduced to values between 60 and $85 \%$. These results indicate the potential for GWWs to reduce peak discharge even from large catchments. Moreover, such modeling approaches also provide tools for deciding on the length, width, and cross-section design of GWWs (Fiener and Auerswald, 2005; Dermisis et al., 2010).

\section{Reduction in Sediment Delivery}

Reduction in sediment delivery is mainly the result of (i) a decrease in transport capacity due to reduced runoff velocities and volumes; (ii) potential sieving of large particles (e.g., aggregates) by dense vegetation and litter; and (iii) infiltration 
of sediment-laden runoff. All three mechanisms are potentially most effective in flat-bottomed, seminatural GWWs (Fig. 2A).

Generally, sediment trapping has been consistently reported to be more effective than runoff reduction (cf. Fig. 5B and Fig. 5A). Mean sediment delivery measured in paired watersheds with and without GWWs (e.g., Chow et al., 1999; Fiener and Auerswald, 2003b) was reduced to $23 \%$ or to $3 \%$ in the watersheds with GWWs. Also, several modeling studies report that sediment delivery is reduced to $28-35 \%$ with 600-m-long GWWs (Hjelmfelt and Wang, 1997; Hjelmfelt and Wang, 1999; Dermisis et al., 2010). The trapping efficiency decreases as more runoff comes from the fields because all three mechanisms of sediment retention become less effective as more runoff concentrates in the GWW (Fig. 5B). Thus, Dermisis et al. (2010) reported much smaller efficiencies for 300-m-long GWWs at high discharge rates $\left(>0.3 \mathrm{~m}^{3} \mathrm{~s}^{-1}\right)$ than what Fiener and Auerswald (2003b) reported for GWWs with similar lengths but much smaller inflow rates (estimated mean $<0.01 \mathrm{~m}^{3} \mathrm{~s}^{-1}$ ). Furthermore, the effects will become larger the more room that is allowed for the runoff to pass the GWW. Wide, seminatural GWWs can thus be expected to have larger effects than GWWs that were engineered to reduce the demand for land.

\section{Reduction in Nutrient and Agrochemical Delivery}

Obviously, retention of runoff and sediment within the GWWs also affects the delivery of dissolved and particle-bound nutrients and agrochemicals. During a 5-yr paired watershed study, GWWs reduced particulate phosphorus losses to 7 and $23 \%$ (Fiener and Auerswald, 2009). The efficiency of particulate-P trapping is directly linked to sediment trapping; however, somewhat smaller effects might be expected because of the typical enrichment of fines and the associated enrichment of phosphorus in delivered sediments (Sharpley, 1980).

Two factors impact the reduction in dissolved substances. The first is the reduction in runoff volume resulting from increased infiltration-and hence the infiltration of dissolved substances. The second effect is more variable. On one hand, the concentration of solubles that originate from the arable land may be reduced by adsorption. This is usually the case for pesticides (Asmussen et al., 1977; Hjelmfelt and Wang, 1997; Briggs et al., 1999). The extent to which the concentration will decrease depends on the extent to which a certain substance interacts with (organic) surfaces. On the other hand, a GWW may also be a source of solubles, such as nutrients, that linger from the former soil use or that accumulate over time in the GWW due to the infiltrating water. Correspondingly, the effects of GWWs on dissolved P may vary. The P concentration did not decrease in one of the GWWs that was analyzed by Fiener and Auerswald (2009), while in the other GWW, the P concentration decreased to $62 \%$. In case of sensitive biotopes downstream, the load and concentration of solubles may be reduced by installing filter socks within the GWW. Shipitalo et al. (2012) showed that such filter socks can decrease the P loads, but other substances by the filter socks. Thus, a GWW can also be a source of solubles. Dissolved organic matter in particular may be released from the debris accumulated within the GWW and thereby raise the concentration compared with field runoff in cases where there is little surface cover in the field to serve as the main source of dissolved organic matter (Glenn and Williams, 1985; Auerswald and Weigand, 1996; Singh et al., 2014). It is important to note, however, that the concentration of any soluble in the throughfall or 
surface runoff decreases during a rain event due to the depletion of the source. The larger the infiltration before runoff starts, the lower will be the concentrations of solubles in the runoff. A GWW with a high infiltration capacity is also advantageous in this respect.

\section{Potential Groundwater Effects}

Additional infiltration along the GWW could potentially turn the GWW into a hotspot of groundwater recharge, which may also affect groundwater quality. The additional recharge is about equal to the reduction in total runoff by the GWW because evapotranspiration of the GWW will increase only to a small degree. Fiener and Auerswald (2003a) estimated an increase in infiltration of about $160 \mathrm{~mm}$ $\mathrm{yr}^{-1}$ within the area of the monitored GWW, which almost doubled the groundwater recharge within the area of the GWW. The effect on the entire watershed area will be much smaller because a GWW constitutes only a few percent of the total watershed land area.

Usually this additional recharge will be of high water quality for two reasons. First, the loading of the GWW with agrochemicals is small because neither fertilizers nor pesticides are applied on a GWW. Second, the runoff from the surrounding fields that infiltrates within the GWW usually does not contain high concentrations of easily soluble agrochemicals, such as nitrate, that pose a risk to groundwater quality. The reason is that runoff from fields occurs only after the initial abstraction has already leached the easily soluble substances from the very top of the arable soil, which interacts with the runoff (usually not more than a few centimeters; Ahuja et al., 1981).

\section{Effects on Plant and Faunal Diversity}

Linear grassland structures within arable fields might play a large role in increasing biodiversity in arable landscapes because they connect different habitats and they provide a different habitat where, in contrast to the surrounding arable land, the application of agrochemicals is low, tillage is missing, and a soil cover is maintained throughout the year (Fig. 1C).

Grassed waterways provide corridors for wildlife and connect patches of fragmented habitats, thus increasing overall habitat quality. In contrast to other linear structural elements-such as buffer strips, riparian areas, terraces, or unplowed strips along field borders-GWWs connect dry upslopes with wet valley bottoms, and they link arable lands that are managed differently. Grassed waterways can thus provide wildlife access to a diversity of habitat resources that are dispersed across the landscape. These effects increase the corridor value of GWWs (Henry et al., 1999). There are, however, few studies of GWWs that focus on these connectivity effects and other ecosystem functions rather than on the potential for soil and water conservation.

The effect on vegetation is usually limited even when the GWW is not sown but is instead developed by succession. Even after $8 \mathrm{yr}$ of succession, the vegetation of such a GWW (Fig. 1C) was dominated by a few fast-growing species commonly found in agricultural landscapes [e.g., Agropyron repens (L.) P. Beauv., Dactylis glomerata L., Urtica dioica L.], some tall herbs (e.g., Epilobium angustifolium L., Galeopsis tetrahit L., Galium aparine L.), and woody plants (e.g., Salix spp., Rubus spp., Sorbus spp.), which contributed between 1 and $15 \%$ to the total cover (Fiener 
and Auerswald, 2003a). The GWW was thus dominated by plants that can commonly be found in intensively used agricultural landscapes. This is not surprising because the colluvial soils along the drainage way promote species that respond to a high concentration of nutrients. Furthermore, an intensively farmed landscape surrounding the GWW does not provide seed sources from other species. The slow invasion of other plants, especial shrubs and trees, offers the advantage of a low-maintenance effort, in which mowing every $10 \mathrm{yr}$ seems to be sufficient to suppress woody species (Fiener and Auerswald, 2003a).

The microbial and faunal effects will be much more pronounced when there is no tillage: the soil microbial biomass will increase and the species composition of the soil fauna will change (Filser et al., 1996). The GWW acts as refuge for epigaeic organisms such as spider and grasshopper species (Agricola et al., 1996) and snakes (Knoot and Best, 2011). As the width of the GWW increases, so does the quality of the habitat quality for all three groups of epigaeic animals. There are also indications that GWWs are a good habitat for birds (Bryan and Best, 1991, 1994; Hultquist and Best, 2001; Fiener and Auerswald, 2003a), but for wide-ranging animals, it becomes more difficult to differentiate between the effects of the various changes in a landscape, such as the introduction of terraces or the reparcellation of the landscape, that usually occur when GWWs are established. To increase the numbers of bird species, especially of those nesting in the GWWs, some studies recommend that these areas should not be mowed until end of August or early September (Bryan and Best, 1991, 1994) and that vegetation should be clipped high (15-30 cm; Bryan and Best, 1994).

\section{The Political Viewpoint}

Clearly, to establish a GWW, considerable financial, organizational, and intellectual effort is required on the part of the farmer, but outreach programs (Shelton et al., 2009; Lemke et al., 2011) and financial incentives can help (Berg and Gray, 1984; Lawler et al., 1992; Kling et al., 2007; Lemke et al., 2010, 2011; Chen and Barkdoll, 2013). Although expensive, such aid appears to be a good investment by society, given that the effective life span of GWWs is long and that experts are involved. The proper design of a GWW will improve its functioning and reduce the risk of failure that could discredit this conservation measure. While there are pros and cons of GWWs for the farmer, for society the benefits clearly outweigh the disadvantages. Evrard et al. (2008b) have shown that the damages from muddy floods are ten times higher than the subsidies Belgian farmers receive for the maintenance of grass strips. Also, the positive effects on biodiversity or aquatic environments clearly should be of societal concern even though they do not figure in the economic considerations of a farmer.

Especially in Europe, public interest in GWWs may grow in future because the sizes of fields have increased enormously in the past and are still doing so (Ankenbrand and Schwertmann, 1989; Chartin et al., 2011; Zádorová et al., 2013). Field borders that cross thalwegs and that are able to trap sediment continuously disappear (by a factor of three during the last $50 \mathrm{yr}$; Boardman and Vandaele, 2016) and will continue to do so. It is not surprising that this loss has resulted in more catchment runoff and peak discharge (Evrard et al., 2007). 


\section{The Scientific Viewpoint}

Major difficulties arise when evaluating GWWs. They require large-scale (watershed) and long-term ( $>5 \mathrm{yr}$ ) research. Scientific standards (replicates, controls) usually cannot be met because there are no two identical watersheds that can be compared with and without GWWs. Even socioeconomic conditions may differ between watersheds because they are so large (Prokopy et al., 2011). The large measuring effort usually means that no replicates are available, and finally, the installation of GWWs is usually accompanied by other measures, such as a change in field layout, that make it difficult to isolate the effect of the GWW. Furthermore, only studies on functional GWWs exist, and studies describing the conditions, frequency, and remediation of failure ones are missing. An interesting although unique approach that solves at least some of these problems was followed by Shipitalo et al. $(2010,2012)$, who used only one watershed but diverted the outflow into two GWWs that could then be compared under near-identical conditions without the need to control the agricultural practices within the entire watershed, which would have been necessary if entire watersheds had been compared.

Because of these limitations, many evaluations have been based on modeling, mainly using SWAT (Soil and Water Assessment Tool; Secchi et al., 2007; Lerch et al., 2008; Luo and Zhang, 2009; Makarewicz et al., 2015), WEPP (Water Erosion Prediction Project; Renschler and Lee, 2005; Zhou et al., 2009; Dermisis et al., 2010; Gassman et al., 2010), or a number of other models (Yaramanoglu, 1986; Gassman et al., 2010; Kalantari et al., 2014; Dabney et al., 2015).

Modeling, however, suffers from the same problems as landscape experiments because models cannot be set up, parameterized, and validated without experimental data. Furthermore, most (erosion) models are optimized mainly for distributed runoff on large areas. Such models cannot reflect in enough detail the conditions governing concentrated flow along permanently grassed narrow paths to allow for realistic hydrodynamic modeling. Even those model approaches technically addressing the GWWs as areas of concentrated flow with specific flow-depth-dependent cross-sectional areas (Temple et al., 1987; Kalantari et al., 2014) face major deficits in three areas of data availability and process representation: (i) Data regarding (potentially changing) cross-sectional areas and inflow pathways affected by agricultural management in the surrounding field are often not available in enough detail. For example, Fiener and Auerswald (2005) showed that a small incision ( $0.5 \mathrm{~m}$ wide and $0.2 \mathrm{~m}$ deep) resulting from linear erosion during the establishment of a GWW substantially reduced the measured and modeled infiltration capacity within a 370-m-long GWW. This lack of detailed data could be addressed in case of individual GWWs via field surveys and might partly be resolved as a result of the improving quality and resolution of digital elevation models. (ii) Our knowledge is limited in parameterizing the hydrodynamic behavior of different grass and herb communities that have varying stem flexibility and inter-stem porosity (Montakhab et al., 2012). Moreover, little is known regarding the changes in the hydrodynamic properties of vegetation throughout the year, knowledge that calls for season-specific parameter sets. The variability of the hydrodynamic parameters of grasses can be illustrated for hydraulic roughness (expressed as Manning's $n$ ). In general, Manning's $n$ in grass-lined channels depends on the density of the grass and is highest and most 
stable for sod-forming vegetation that has a dense, relatively deep root system (e.g., Bermuda grass [Cynodon dactylon (L.) Pers.]; USDA-SCS, 1954). Depending on flow depths and velocity, plants may change their position, start oscillating (USDA-SCS, 1954), or even bend or break if there are high runoff velocities and large runoff depths (Kouwen and Unny, 1973). For dense, sod-forming grasses, Manning's $n$ decreases with increasing flow velocity and depths (often expressed as the product of flow velocity and hydraulic radius), from values between 0.3 and $0.4 \mathrm{~s} \mathrm{~m}^{-1 / 3}$ (Ree, 1949; USDA-SCS, 1954; Kouwen, 1992) to values between 0.03 and $0.1 \mathrm{~s} \mathrm{~m}^{-1 / 3}$ (USDA-SCS, 1954; Kouwen and Unny, 1973). It is difficult to predict whether bending or breaking will occur. Both depend not only on the flow velocity and depths, but they are also governed by the seasonally changing hydraulic properties of the grass canopy. Moreover, there is little knowledge regarding the recovery of the hydraulic properties of grasses and herbs after being bent (Fiener and Auerswald, 2006b). (iii) The parameterization of soil properties is limited by the fact that at least during the first few years after establishment, the soil passes through a transition phase, with parameters changing between the former arable use and a typical grassland soil. Compared with common grassland, after the transition phase there may be major differences due to the belt shape of a GWW, which may result in mammal burrows preferentially following the long axis and thereby affecting runoff behavior. This suggestion is, however, speculative.

Surprisingly little experimental evidence exists about the ecological benefits and drawbacks of GWWs (Henry et al., 1999), although this absence should be of major concern to society because it would justify incentives for the installation of GWWs. Experimental evidence would supply knowledge about optimizing design and maintenance in this respect. This deficit is partly caused by the same difficulty that studies on erosion control have; namely, that no two identical watersheds exist that differ only in the existence of a GWW. However, such studies may exist but cannot be found because terms like "set-aside" or "grassland" are used in place of the proper technical term, "grassed waterway." . This may occur because the technical term is unknown to specialists in other fields, such as arachnology, herpetology, or aquatic ecology, or that the term is avoided to attract a wider audience and to make the results more generally applicable. For example, most studies cited above regarding the influence of GWWs on species dynamics (Agricola et al., 1996; Filser et al., 1996; Mebes and Filser, 1997) avoid using "grassed waterway." As a result, the knowledge that these studies concerned GWWs was restricted to the few persons who became aware of the studies during the short period of fieldwork.

The lack of proper ecological studies on GWWs is even more regrettable because GWWs behave differently than set-asides or grasslands in many respects, such as in the corridor shape, the position within the landscape connecting valley bottoms with upslope positions, and the frequent input of water carrying soil, nutrients, and other substances. Hence, GWWs would be mischaracterized if experiences from set-asides or grasslands were applied to them. Alternatively, grasslands and set-asides are equally mischaracterized if, in fact, it is GWWs that have been studied. Also, GWWs and filter strips are frequently treated as similar because both are narrow strips of land covered with permanent vegetation. This is, however, misleading in several hydrological, ecological, and agronomic 
respects. For example, it is the length of the flow path that governs infiltration, and there is no larger difference in the length of the flow path than that between those of a GWW and a filter strip. Another difference is whether the narrow strip connects different habitats or runs within one riparian habitat. Another difference is whether a narrow strip can be crossed by farm machinery or whether this is impossible due to an adjacent watercourse. Hence, given the diversity of beneficial on-site and off-site effects that seem to exist, there is a clear and pressing need for more direct studies on GWWs and less deduction by analogy.

\section{References}

Agricola, U., J. Barthel, H. Laussmann, and H. Plachter. 1996. Struktur und Dynamik der Fauna einer süddeutschen Agrarlandschaft nach Nutzungsumstellung auf ökologischen und integriereten Landbau. Verh. Ges. Ökol. 26:681-692.

Ahuja, L.R., A.N. Sharpley, M. Yamamoto, and R.G. Menzel. 1981. The depth of rainfall-runoff-soil interaction as determined by 32P. Water Resour. Res. 17:969-974. doi:10.1029/ WR017i004p00969

Ankenbrand, E., and U. Schwertmann. 1989. The land consolidation project of Freinhausen, Bavaria. In: U. Schwertmann; R.J. Rickson; K. Auerswald, editors, Soil erosion measures in Europe. Proceedings of the European Community Workshop on Soil Erosion Protection, Freising, Germany. 24-26 May 1988. Soil Technology Series 1. Catena Verlag, Reiskirchen, Germany. p. 167-173.

Asmussen, L.E., A.W. White, Jr., E.W. Hauser, and J.M. Sheridan. 1977. Reduction of 2,4D load in surface runoff down a grassed waterway. J. Environ. Qual. 6:159-162. doi:10.2134/ jeq1977.00472425000600020011x

Atkins, D.M., and J.J. Coyle. 1977, Grass waterways in soil conservation. USDA Leaflet 477. U.S. Gov. Print. Office, Washington, D.C

Auerswald, K., and S. Weigand. 1996. Ecological impact of dead-wood hedges: Release of dissolved phosphorus and organic matter into runoff. Ecol. Eng. 7:183-189. doi:10.1016/0925-8574(96)00007-9

Bracmort, K.S., B.A. Engel, and J.R. Frankenberger. 2004. Evaluation of structural best management practice 20 years after installation: Black Creek' watershed, Indiana. J. Soil Water Conserv. 59:191-196.

Berg, N.A., and R.J. Gray. 1984. Soil conservation: "The search for solutions." J. Soil Water Conserv. 39:18-22.

Boardman, J., and K. Vandaele. 2016. Effect of the spatial organization of land use on muddy flooding from cultivated catchments and recommendations for the adoption of control measures. Earth Surf. Process. Landf. 41:336-343. doi:10.1002/esp.3793

Briggs, J.A., T. Whitwell, and M.B. Riley. 1999. Remediation of herbicides in runoff water from container plant nurseries utilizing grassed waterways. Weed Technol. 12:157-164.

Bryan, G.G., and L.B. Best. 1991. Bird abundance and species richness in grassed waterways in lowa rowcrop fields. Am. Midl. Nat. 126:90-102. doi:10.2307/2426153

Bryan, G.G., and L.B. Best. 1994. Avian nest density and success in grassed waterways in Iowa rowcrop fields. Wildl. Soc. Bull. 22:583-592.

Carey, B.W., B. Stone, P.L. Norman, and P. Shilton. 2015a. Waterways In: Soil conservation guidelines for Queensland. Chap. 9. Dep. of Science, Information Technology and Innovation, Brisbane. p. 1-19. https://publications.qld.gov.au/dataset/e9116bae-b8434b61-8050-433898222bd6/resource/125aadac-0c22-4564-98a6-98e6leee1f6e/download/ soilconguide3echapter9.pdf (accessed 31 Dec. 2016).

Carey, B.W., B. Stone, P.L. Norman, and P. Shilton. 2015b. Soil conservation in horticulture In: Soil conservation guidelines for Queensland. chap 12. Dep. of Science, Information Technology and Innovation, Brisbane. p. 1-45. https://publications.qld.gov.au/ dataset/e9116bae-b843-4b61-8050-433898222bd6/resource/e416f81e-d0e6-4245-a1d1961070a566a2/download/chapter12horticulture.pdf (accessed 31 Dec. 2016). 
Chartin, C., H. Bourennane, S. Salvador-Blanes, F. Hinschberger, and J.-J. Macaire. 2011. Classification and mapping of anthropogenic landforms on cultivated hillslopes using DEMs and soil thickness data: Example from the SW Parisian Basin, France. Geomorphology 135:8-20. doi:10.1016/j.geomorph.2011.07.020

Chen, L., and B.D. Barkdoll. 2013. Optimal location of watershed best management practices for sediment yield, reduction and cost. In: C.L. Patterson, S.S. Struck, and D.J. Murray, editors, Showcasing the future. World Environmental and Water Resources Congress 2013, Cincinnati, Ohio. 19-23 May. American Society of Civil Engineers, Reston, VA. p. 3183-3195. doi:10.1061/9780784412947.315

Chow, T.L., H.W. Rees, and J.L. Daigle. 1999. Effectiveness of terraces/grassed waterway systems for soil and water conservation: A field evaluation. J. Soil Water Conserv. 3:577-583.

Dabney, S.M., D.A.N. Vieira, D.C. Yoder, E.J. Langendoen, R.R. Wells, and M.E. Ursic. 2015. Spatially distributed sheet, rill, and ephemeral gully erosion. J. Hydrol. Eng. 20(6). doi:10.1061/(ASCE)HE.1943-5584.0001120

Dass, A., S. Sudhishri, N.K. Lenka, and U.S. Patnaik. 2011. Runoff capture through vegetative barriers and planting methodologies to reduce erosion, and improve soil moisture, fertility and crop productivity in southern Orissa, India. Nutr. Cycling Agroecosyst. 89:45-57. doi:10.1007/s10705-010-9375-3

Deletic, A. 2001. Modelling of water and sediment transport over grassed areas. J. Hydrol. 248:168-182. doi:10.1016/S0022-1694(01)00403-6

Dermisis, D., O. Abaci, A.N. Papanicolaou, and C.G. Wilson. 2010. Evaluating grassed waterway efficiency in southeastern Iowa using WEPP. Soil Use Manage. 26:183-192. doi:10.1111/j.1475-2743.2010.00257.x

Dillaha, T.A., R.B. Reneau, S. Mostaghimi, and D. Lee. 1989. Vegetative filter strips for agricultural nonpoint source pollution control. Trans. ASAE 32:513-519. doi: $10.13031 / 2013.31033$

Evrard, O., E. Persoons, K. Vandaele, and B. van Wesemael. 2007. Effectiveness of erosion mitigation measures to prevent muddy floods: A case study in the Belgian loam belt. Agric. Ecosyst. Environ. 118:149-158. doi:10.1016/j.agee.2006.02.019

Evrard, O., K. Vandaele, C. Bielders, and B. Van Wesemael. 2008a. Seasonal evolution of runoff generation on agricultural land in the Belgian loess belt and implications for muddy flood triggering. Earth Surf. Processes Landforms 33:1285-1301. doi:10.1002/esp.1613

Evrard, O., K. Vandaele, B. Van Wesemael, and C.L. Bielders. 2008b. A grassed waterway and earthen dams to control muddy floods from a cultivated catchment of the Belgian loess belt. Geomorphology 100:419-428. doi:10.1016/j.geomorph.2008.01.010

Fiener, P., and K. Auerswald. 2003a. Concept and effects of multi-purpose grassed waterway. Soil Use Manage. 19:65-72. doi:10.1111/j.1475-2743.2003.tb00281.x

Fiener, P., and K. Auerswald. 2003b. Effectiveness of grassed waterways in reducing runoff and sediment delivery from agricultural watersheds. J. Environ. Qual. 32:927-936. doi:10.2134/jeq2003.9270

Fiener, P., and K. Auerswald. 2005. Measurement and modeling of concentrated runoff in a grassed waterway. J. Hydrol. 301:198-215. doi:10.1016/j.jhyd rol.2004.06.030

Fiener, P., and K. Auerswald. 2006a. Influence of scale and land use pattern on the efficacy of grassed waterways to control runoff. Ecol. Eng. 27:208-218. doi:10.1016/j. ecoleng.2006.02.005

Fiener, P., and K. Auerswald. 2006b. Seasonal variation of grassed waterway effectiveness in reducing runoff and sediment delivery from agricultural watersheds in temperate Europe. Soil Tillage Res. 87:48-58.-doi:10.1016/j.still.2005.02.035

Fiener, P., and K. Auerswald. 2009. Effects of hydrodynamically rough grassed waterways on dissolved reactive phosphorus loads coming from agricultural watersheds. J. Environ. Qual. 38:548-559. doi:10.2134/jeq2007.0525

Filser, J., A. Lang, K.-H. Mebes, S. Mommertz, A. Palojärvi, and K. Winter. 1996. The effect of land use change on soil organisms: An experimental approach. Verh. Ges. Ökol. 26:671-679. 
Gassman, P.W., J.R. Williams, X. Wang, A. Saleh, E. Osei, L.M. Hauck, R.C. Izaurralde, and J.D. Flowers. 2010. The Agricultural Policy/Environmental eXtender (APEX) model: An emerging tool for landscape and watershed environmental analyses. Trans. ASABE 53:711-740. doi:10.13031/2013.30078

Glenn, S., and G.H. Williams. 1985. Nonpoint source loading of phenolic acids from decomposing crop residue. Soil Tillage Res. 6:45-51. doi:10.1016/0167-1987(85)90005-4

Gordon, L.M., S.J. Bennett, C.V. Alonso, and R.L. Bingner. 2008. Modeling long-term soil losses on agricultural fields due to ephemeral gully erosion. J. Soil Water Conserv. 63:173-181. doi:10.2489/jswc.63.4.173

Henry, A.C., D.A. Hosack, C.W. Johnson, D. Rol, and G. Bentrup. 1999. Conservation corridors in the United States: Benefits and planning guidelines. J. Soil Water Conserv. 54:645-65.

Hjelmfelt, A., and M. Wang. 1997. Using modelling to investigate impacts of grass waterways on water quality. In: F.M. Holly and A. Alsoffar, editors, Water for a changing global community. Proceedings of the 27th International Association of Hydraulic Research (IAHR) World Congress, San Francisco, CA. 10-15 August. American Society of Civil Engineers, Reston, VA. p. 1420-1425.

Hjelmfelt, A., and M. Wang. 1999. Modeling hydrologic and water quality responses to grass waterways. J. Hydrol. Eng. 4:251-256. doi:10.1061/(ASCE)1084-0699(1999)4:3(251)

Hultquist, J.M., and L.B. Best. 2001. Bird use of terraces in Iowa row crop fields. Am. Midl. Nat. 145:275-287. doi:10.1674/0003-0031(2001)145[0275:BUOTII]2.0.CO;2

Kalantari, Z., S.W. Lyon, L. Folkeson, H.K. French, J. Stolte, P.E. Jansson, and M. Sassner. 2014. Quantifying the hydrological impact of simulated changes in land use on peak discharge in a small catchment. Sci. Total Environ. 466-467:741-754. doi:10.1016/j. scitotenv.2013.07.047

Kling, C., S.S. Rabotyagov, M. Jha, H. Feng, J. Parcel, P.W. Gassman, and T. Campbell. 2007. Conservation practices in lowa: Historical investments, water quality, and gaps. A report to the Iowa farm bureau and partners. http://citeseerx.ist.psu.edu/viewdoc/dow nload?doi=10.1.1.568.7680\&rep=rep1\&type=pdf (accessed 31 Dec. 2016).

Knoot, T.G., and L.B. Best. 2011. A multiscale approach to understanding snake use of conservation buffer strips in an agricultural landscape. Herpetol. Conserv. Biol. 6:191-201.

Kouwen, N., 1992. Modern approach to design of grassed channels. J. Irrig. Drain. Div., Am. Soc. Civ. Eng. 118:733-743.

Kouwen, N., and T.E. Unny. 1973. Flexible roughness in open channels. J. Hydraul. Div., Am. Soc. Civ. Eng. 99:713-728.

Lawler, D.M., M. Dolan, H. Tomasson, and S. Zophoniasson. 1992. Temporal variability of suspended sediment flux from a subarctic glacial river, southern Iceland. In: J. Bogen, D.E. Walling, and T.J. Day, editors, Erosion and sediment transport monitoring programmes in river basins. Proceedings of the International Symposium, Oslo, Norway. 24-28 August. IAHS Proceedings and Reports, Walling ford, UK. p. 233-243.

Lemke, A.M., K.G. Kirkham, T.T. Lindenbaum, M.E. Herbert, T.H. Tear, W.L. Perry, and J.R. Herkert. 2011. Evaluating agricultural best management practices in tile-drained subwatersheds of the Mackinaw River, Illinois. J. Environ. Qual. 40:1215-1228. doi:10.2134/ jeq2010.0119

Lemke, A.M., T.T. Lindenbaum, W.L. Perry, M.E. Herbert, T.H. Tear, and J.R. Herkert. 2010. Effects of outreach on the awareness and adoption of conservation practices by farmers in two agricultural watersheds of the Mackinaw River, Illinois. J. Soil Water Conserv. 65:304-315. doi:10.2489/jswc.65.5.304

Lerch, R.N., E.J. Sadler, N.R. Kitchen, K.A. Sudduth, R.J. Kremer, D.B. Myers, C. Baffaut, S.H. Anderson, and C.H. Lin. 2008. Overview of the Mark Twain Lake/Salt River basin conservation effects assessment project. J. Soil Water Conserv. 63:345-359. doi:10.2489/ jswc.63.6.345

Luck, J.D., S.K. Pitla, R.S. Zandonadi, M.P. Sama, and S.A. Shearer. 2011a. Estimating off-rate pesticide application errors resulting from agricultural sprayer turning movements. Precis. Agric. 12:534-545. doi:10.1007/s11119-010-9199-9 
Luck, J.D., R.S. Zandonadi, and S.A. Shearer. 2011b. A case study to evaluate field shape factors for estimating overlap errors with manual and automatic section control. Trans. ASABE 54:1237-1243. doi:10.13031/2013.39022

Luo, Y.Z., and M.H. Zhang. 2009. Management-oriented sensitivity analysis for pesticide transport in watershed-scale water quality modeling using SWAT. Environ. Pollut. 157:3370-3378. doi:10.1016/j.envpol.2009.06.024

Makarewicz, J.C., T.W. Lewis, M. Winslow, E. Rea, L. Dressel, D. Pettenski, B.J. Snyder, P. Richards, and J. Zollweg. 2015. Utilizing intensive monitoring and simulations for identifying sources of phosphorus and sediment and for directing, siting, and assessing BMPs: The Genesee River example. J. Great Lakes Res. 41:743-759. doi:10.1016/j. jglr.2015.06.004

Mebes, K.-H., and J. Filser. 1997. A method for estimating the significance of surface dispersal for population fluctuations of Collembola in arable land. Pedobiologia 41:115-122.

Montakhab, A., B. Yusuf, A.H. Ghazali, and T.A. Mohamed. 2012. Flow and sediment transport in vegetated waterways: A review. Rev. Environ. Sci. Biotechnol. 11:275-287. doi:10.1007/s11157-012-9266-y

Muñoz-Carpena, R., J.E. Parson, and J.W. Gilliam. 1993. Numerical approach to the overland flow process in vegetative filter strips. Trans. ASAE 36:761-770. doi:10.13031/2013.28395

Napier, T.L., C.S. Thraen, A. Gore, and W.R. Goe. 1984. Factors affecting adoption of conventional and conservation tillage practices in Ohio. J. Soil Water Conserv. 39:205-209.

Nyaupane, N.P., and J.M. Gillespie. 2011. Louisiana crawfish farmer adoption of best management practices. J. Soil Water Conserv. 66:61-70. doi:10.2489/jswc.66.1.61

Ogunlela, A.O., and M.B. Makanjuola. 2000. Hydraulic roughness of some African grasses. J. Agric. Eng. Res. 75:221-224. doi:10.1006/jaer.1999.0486

Osmond, D., D. Meals, D. Hoag, M. Arabi, A. Luloff, G. Jennings, M. McFarland, J. Spooner, A. Sharpley, and D. Line. 2012. Improving conservation practices programming to protect water quality in agricultural watersheds: Lessons learned from the National Institute of Food and Agriculture-Conservation Effects Assessment Project. J. Soil Water Conserv. 67:122A-127A. doi:10.2489/jswc.67.5.122A

Prokopy, L.S., A.Z. Göçmen, J. Gao, S.B. Allred, J.E. Bonnell, K. Genskow, A. Molloy, and R. Power. 2011. Incorporating social context variables into paired watershed designs to test nonpoint source program effectiveness. J. Am. Water Resour. Assoc. 47:196-202.

Qiu, Z., C. Hall, and K. Hale. 2009. Evaluation of cost-effectiveness of conservation buffer placement strategies in a river basin. J. Soil Water Conserv. 64:293-302. doi:10.2489/ jswc.64.5.293

Ree, W.O. 1949. Hydraulic characteristics of vegetation for vegetated waterways. Agric. Eng. 30:184-187.

Renschler, C.S. and T. Lee. 2005. Spatially distributed assessment of of short-and long-term impacts of multiple best management practices in agricultural watersheds. Journal of Soil and Water Conservation 60: 446-456.

Secchi, S., P.W. Gassman, M. Jha, L. Kurkalova, H.H. Feng, T. Campbell, and C.L. Kling. 2007. The cost of cleaner water: Assessing agricultural pollution reduction at the watershed scale. J. Soil Water Conserv. 62:10-21.

Sharpley, A.N. 1980. The enrichment of soil phosphorus in runoff sediments. J. Environ. Qual. 9:521-526. doi:10.2134/jeq1980.00472425000900030039x

Shelton, D.P., R.A. Wilke, T.G. Franti, and S.J. Josiah. 2009. Farmlink: Promoting conservation buffers farmer-to-farmer. Agrofor. Syst. 75:83-89. doi:10.1007/s10457-008-9130-9

Shipitalo, M.J., J.V. Bonta, E.A. Dayton, and L.B. Owens. 2010. Impact of grassed waterways and compost filter socks on the quality of surface runoff from corn fields. J. Environ. Qual. 39:1009-1018. doi:10.2134/jeq2009.0291

Shipitalo, M.J., J.V. Bonta, and L.B. Owens. 2012. Sorbent-amended compost filter socks in grassed waterways reduce nutrient losses in surface runoff from corn fields. J. Soil Water Conserv. 67:433-441. doi:10.2489/jswc.67.5.433

Singh, S., S. Inamdar, M. Mitchell, and P. McHale. 2014. Seasonal pattern of dissolved organic matter (DOM) in watershed sources: Influence of hydrologic flow paths and autumn leaf fall. Biogeochemistry 118:321-337. doi:10.1007/s10533-013-9934-1 
Spaan, W., H. Winteraeken, and P. Geelen. 2010. Adoption of SWC measures in South Limburg (The Netherlands): Experiences of a water manager. Land Use Policy 27:78-85. doi:10.1016/j.landusepol.2008.10.015

Temple, D.M., K.M. Robinson, R.M. Ahring, and A.G. Davis. 1987. Stability design of grasslined open channels. Agric. Handb. 667. USDA-ARS, Washington, DC. http://www.fcd. maricopa.gov/pub/docs/scanfcdlibrary\%5C101_302_StabilityDesignofGrass_linedOpenChannels.pdf (accessed 31 Dec. 2016).

Thomas, G.A., G.W. Titmarsh, D.M. Freebairn, and B.J. Radford. 2007. No-tillage and conservation farming practices in grain growing areas of Queensland: A review of 40 years of development. Aust. J. Exp. Agric. 47:887-898. doi:10.1071/EA06204

Titmarsh, G.W., and B.J. Stone. 1997. Runoff management: Techniques and structures. In: A.L. Clarke and P.B. Wylie, editors, Sustainable crop production in the sub-tropics: An Australian perspective. Department of Primary Industries, Queensland, Australia. p. 181-194.

USDA Soil Conservation Service (USDA-SCS). 1954. Handbook of channel design for soil and water conservation. USDA-SCS, Washington, DC. http://www.wcc.nrcs.usda.gov/ ftpref/wntsc/H\&H/TRsTPs/TP61.pdf (accessed 31 Dec. 2016).

Van Oost, K., G. Govers, and P. Desmet. 2000. Evaluating the effects of changes in landscape structure on soil erosion by water and tillage. Landsc. Ecol. 15:577-589. doi:10.1023/A:1008198215674

Yaramanoglu, M. 1986. Microcomputer-based interactive design of grassed waterways. Comput. Electron. Agric. 1:173-184. doi:10.1016/0168-1699(86)90005-0

Zádorová, T., V. Penižek, L. Sefrna, O. Drábek, M. Mihaljevič, S. Volf, and T. Chuman. 2013. Identification of Neolithic to modern erosion-sedimentation phases using geochemical approach in a loess covered sub-catchment of South Moravia, Czech Republic. Geoderma 195-196:56-69. doi:10.1016/j.geoderma.2012.11.012

Zhou, X., M. Helmers, M. Al-Kaisi, and M. Hanna. 2009. Cost-effectiveness and cost-benefit analysis of conservation management practices for sediment reduction in an lowa agricultural watershed. J. Soil Water Conserv. 64:314-323. doi:10.2489/jswc.64.5.314 